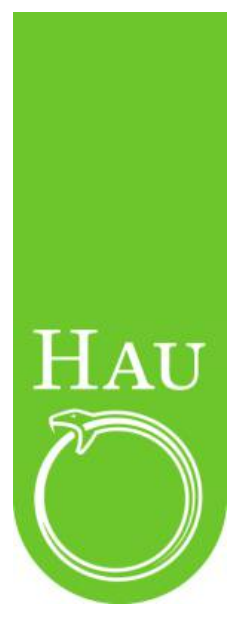

2018|HAU: Journal of Ethnographic Theory 8 (1/2): 292-299

\author{
SPECIAL SECTION \\ ANTHROPOLOGIES OF DESTINY: \\ ACTION, TEMPORALITY, FREEDOM
}

PREFACE

\title{
For an anthropology of destiny
}

\author{
Alice ElLiot, Goldsmiths, University of London \\ Laura Menin, University of Milano Bicocca
}

This preface develops an argument for a comparative anthropology that takes the concept of destiny as a fertile laboratory for anthropological thought. The articles in this collection show how destiny's distinguishing heuristic feature may be what we call "malleable fixity": a paradoxical juxtaposition of images of temporal and historical fixity with a practical reckoning and openended self-reorientation. Exploring the radically different ways in which destiny is evoked, enacted, and (re)theorized locally, we argue that an anthropology of destiny is, at its heart, the comparative study of diverse temporal orderings of human-as well as divine and cosmic - action.

Keywords: destiny, malleable fixity, action, temporality, freedom

What does it mean to live a life that has already been written? How does one understand the past and prepare for the future when determining forces intersect with human action and imagination? This collection is a close, comparative study of the conceptual and ethnographic powers of “destiny.” Tracing destiny's manifestations across different regions and religious traditions, our aim is to provide ethnographic depth and breadth to what are centuries-old philosophical questions about, and classic anthropological engagements with, ideas of destiny. In doing this, our ambition is to discover destiny's distinct potential for fresh ethnographic theorizations of the multiple ways in which people imagine and reckon with determining powers.

Questions surrounding humans' capacity to act and effect change when life and possibility are partially or wholly determined by external, often nonnegotiable, powers have long been at the core of theological and philosophical traditions - from the ancient Greek notion of moira and early Asian philosophies of karma, to centuries-old Islamic debates on the concept of qada ${ }^{\prime}$ wa'l-qadar (God's decree and determination). In anthro- pology, classic works such as Oedipus and Job in West African religion by Meyer Fortes (1959) as well as contemporary ethnographic discussions of fate and destiny (da Col and Humphrey 2012a, 2012b; Festa 2007; Guenzi 2013; Hamdy 2009; Harrell 1987; Hatfield 2002; Nieswand 2010; Sangren 2012) testify to destiny's key role in local thinking and practice.

Building on this rich scholarship, in this collection we begin to outline the contours of an anthropology of destiny and develop a comparative framework for the concept's multiple ethnographic manifestations and theorizations, bringing into conversation the Islamic notions of qadar/nasib of the Yemeni highlands (Luca Nevola) with the "corporeal destiny" of Fijian rugby players (Daniel Guinness) and the concept of mingyun of Taiwanese mantic art specialists (Stéphanie Homola). In doing so, we also reveal the linguistic, epistemological, and indeed ontological challenges of engaging with destiny as a unified object of anthropological analysis. Vast as the cosmos and as specific as the reason for missing an appointment, able to explain anything but not everything, destiny is deeply fluid, ambivalent, and theoretically 
slippery. Its radically varied ethnographic imaginations interrogate the very possibility of a comparative project, particularly when it involves engulfing such generative difference within the English term destiny, itself a polysemic and historically contingent linguistic category (Bargdill 2006). While all the articles in the collection engage with nuance and care with the possibilities and limits of anthropological translation, in this preface we want to delineate some of the distinctive qualities and possible comparative coordinates for thinking of destiny (and its multiple permutations) as a productive ethnographic concept for theorizing contemporary social and intimate life.

The idea guiding this collection is twofold. First, distinctly from notions of "randomness" and "chance," destiny evokes conceptions of human lives and futures that are, at least partly, fixed - be it by high political powers, cosmic forces, or transcendental entities. Second, such fixity is fundamentally malleable-destiny is negotiated and nurtured, manipulated and resisted in complex ways, and unavoidably inflected by other powers ranging from cosmological elements such as fortune and luck to intimate others such as kin. Indeed, perhaps what makes destiny most distinct as an anthropological category is that its fixity is unhinged. This peculiar - even paradoxical-quality opens, we argue, incredible potential for comparative anthropological work on productive tensions between fixity and malleability, human and divine power, freedom and constraint, certainty and unpredictability. An "anthropology of destiny" is, in this sense, a comparative anthropology of the multiple ways in which people conceptualize, imagine, and reckon with different forms of what we call "malleable fixity."

In this preface, we outline three key sets of questions brought to the fore by the collection's engagement with destiny and its malleable fixity. In doing so, we delineate three productive coordinates for thinking about destiny anthropologically. First, What makes destiny distinct from other forces and powers, and what conceptual possibility (or possibilities) does this distinctiveness open? Second, What theories of "agency" and "freedom" emerge from lives that are imagined as the result of divine and human will? Third, What happens to ideas of time when past, present, and future are conceived as variedly fixed, drawn, written, or allotted by greater powers? Exploring these questions through the radically different ways in which destiny is evoked, enacted, and (re)theorized locally, we argue that an anthropology of destiny is, at its heart, the comparative study of diverse temporal orderings of human - as well as divine and cosmic - action.

\section{Malleable fixity}

Anthropology often discusses destiny in conjunction with other powerful forces and entities such as luck and fortune, providence and chance. This analytic aggregation reflects the ethnographic porousness of these concepts and vocabularies in everyday life, where they are often contextually invoked, in varying combinations, to make sense or actively nurture success (D’Angelo 2015; Douglas [1966] 2001) and divine blessing (Jamous 1981), fortune and luck (da Col 2012; Gaibazzi and Gardini 2015; Menin 2016) and wellbeing (Lambek 1993), or to make past events and uncertain futures partially intelligible (Evans-Pritchard 1976; Guenzi 2013; Hatfield 2002; Holbraad 2012). As Vincent Crapanzano puts it: "There is probably no society that explains every contingent event in terms of a single power, though when pushed for an explanation, they may refer to such power. Rather ... there seems to be ever-shifting reference to different causes of contingency" (2014: 163).

While influenced by Crapanzano's warning against sacrificing, through an "analytically justified ordering," the "half-disciplined chaos" of contingency (2014: 159), one of the aims of this collection is precisely to extricate the concept of destiny from the web of related concepts and idioms. This is because, we feel, there is untapped theoretical potential in destiny as an ethnographic category in its own right.

We argue that destiny's compelling distinctiveness directly emanates from within its peculiar "malleable fixity." While sometimes luck, fortune, and even chance present some "fixed" qualities, fixity remains a constant question and concern in anthropological reckonings with destiny (see also da Col and Humphrey 2012a: 15; Elliot 2016: 492-94; Gaibazzi and Gardini 2015: 204), making it a useful distinguishing heuristic in an otherwise radically diverse semantic and experiential field. It is fixity that is contained in the Latin word destinare (make firm, establish, fix), and in destiny's corollary notion of predestination (from the Latin predestinare, make firm beforehand). An idea of fixity is present also in the Islamic theology of qadā wa qadar, where qada' indicates divine decrees about major events in people's lives, written $a b$ eterno since the beginning of times. This idea of a (varyingly) "fixed" transcendental writing, plan, or conjuncture is present also in Hindu 
conceptions of headwriting (Kent 2009), karma (Keyes and Daniel 1983), and astrology (Guenzi 2013).

Destiny's (varying) fixity is generally understood as being imposed, willed, or spawned by spiritual, supernatural, or cosmological forces - and it is with this broad religious dimension of destiny (from the decreeing Muslim God in Nevola's article to the Chinese Heaven addressed by Homola) that we are mainly concerned with in this collection. A greater order, or scale, of magnitude, however, is implied also in more "secular" idioms surrounding destiny's fixity-from Karl Marx's "historical destiny" and theorizations of history as the unfolding of necessary events (Palmié and Stewart 2015), to the determinist language surrounding "chromosomal destiny" (Rapp, Heath, and Taussig 2001), to the fatalism of Western bureaucracy of Michael Herzfeld's (1992) classic analysis. Divine or chromosomal, historical or individualized, destiny compels people to reckon with the limits and possibilities determined, willed, or known by a greater order, one that supersedes the scale of individual lives and personal wills, and is often experienced or narrated a posteriori as necessary and inescapable.

Crucially, such fixed, predetermined, even necessary qualities of destiny tend to be of a distinctly malleable nature. In the anthropological literature as in our own field sites, we rarely encounter "destiny" without also encountering manipulation and negotiation, prediction and divination, interpretation and creativity. It is precisely the paradoxical contraposition of conceptions of (temporal, personal, historical) fixity with the deeply malleable understandings of, and reckoning with, the concept that, we argue, makes destiny such a fertile laboratory for anthropological thought. In her mention of destiny in Purity and danger, Mary Douglas ([1966] 2001: 83-84) points out that while destiny cannot, by definition, be changed completely, different societies and religious traditions accord radically different degrees of malleability to the concept.

Such (variable) malleable fixity is precisely what emerges from the articles in this collection. Among Fijian rugby players (Guinness), destiny is conceptualized as an embodied encounter between divine, ethno-nationalist, and professional destinies, and this multiplicity of destinies is both revealed in and realized through the individual's work on his body. In Yemen (Nevola), the tensions between the fixity and malleability of destiny emerges as the dynamic relationship between qadar, the "power to act" within limits fixed by God's decree, and nasib, the nonnegotiable closure of this horizon of possibilities.
In Chinese cosmologies (Homola), it is an impersonal Heaven that determines human destiny, and malleable fixity is contained within the very concept of mingyun (fate/destiny), ming being the fixed dimension of fate, and yun the "motile" one.

The different forms of malleable fixity explored in this collection reveal that destiny is not a singular conceptual or ethnographic model but rather a contested field whose different permutations require careful negotiations throughout the course of people's lives, opening crucial questions about human participation in "fixed" events, process, and temporalities.

\section{Acting within limits}

Reflections on the possibilities of human freedom, agency, and intentionality vis-à-vis greater determining orders are at the core of many theological imaginations of destinyfrom Christian reflections on the possible co-occurrence of liberum arbitrium and divine providentia, to centuriesold Islamic debates on the relationship between divine decree and human free will (see De Cillis 2014). The tension between divine destiny and human action has triggered also much of the classic works on destiny within and beyond anthropology. This tension lies at the heart of Max Weber's (2010) classic opus on destiny in early Protestantism, where he attends to the apparent paradox of the coupling of a steadfast belief in predetermined salvation with intense human action oriented toward it: "as if," coupled with "elective affinity," becomes Weber's ingenious solution to the paradox of destiny and human action (Giddens 2010). ${ }^{1}$ Similarly, in his landmark anthropological work on destiny, Fortes (1959) explores the problem of divine predestination and everyday existence by tracing Tallensi modes of societal incorporation. Here, good and evil prenatal destinies are worked through to obtain both successful incorporation of an individual in society, and the person's obedience to parents and ancestors. For Fortes, the "fixity" of prenatal destiny is invariably molded by the flexibility of kinship relations - an insight that, as Giovanni da Col notes (2012: 13), directly influenced Edmund Leach's classification of affine relations as founded on "mystical alliance."

1. For an ethnographic engagement with Weber's "theory of destiny," see Elliot (2016) and Nevola (this issue).

2. See also Caterina Guenzi's (2013) discussion of the constitutive role of affinal and kin relationships in individual destinies in her ethnography of astrology in Benares. 
As Homola shows, the productive tension between divine and human action also runs deep in the anthropological scholarship on fate and destiny in Asia. Classic comparative explorations of notions of karma (Keyes and Daniel 1983; Obeyesekere 2002) and fate (Ingersoll 1966) as well as work on the Chinese concept of mingyun (Harrell 1987; Lupke 2005), show that, just as Weber and Fortes argue, the involvement of greater determining powers in human lives does not prevent people from acting strategically, often by resorting to specific cultural practices and selected experts. Attending to the tension between immutable destiny and human action and choice at the heart of Taiwanese chhiam divination, Donald Hatfield concludes that, "the theory of fate . . . is more than a consideration of the possible. It is an attempt to act outside of the determination imposed by a given situation" (2002: 871).

Discussing ideas of destiny in West Africa, Michael Jackson also approaches, through an existential frame, the paradox of human participation in divine destiny, describing it as a tension between "what is given and what is chosen in social existence" (1988: 193). Jackson points explicitly to the malleability of destiny: "although people often speak of divine will or ancestral influence in terms of implacable fate, it is always human choice which, in practice, determines the particular course of a person's destiny" (199). Similarly, Babatunde Lawal (1985) writes that, in Yoruba thought, personal destiny (ori) is conceived as a potentiality, its actualization hinging on individuals' active participation - a point recalled in Boris Nieswand's (2010) contemporary work with West Africans in Berlin, where a specific Christian charismatic imaginary of "enacted destiny" sees human and divine agencies merging to realize God's inscrutable plans (cf. Guinness's concept of "corporeal destiny”).

Variously raised by philosophers, theologians, anthropologists, and our own ethnographic interlocutors, the role of human participation in destiny (be it divine, cosmological, prenatal, or other) emerges as a fundamental ethical, existential, and theoretical question. Indeed, the tension between acting and "being acted upon" (Mittermaier 2012), often at the heart of local theorizations of destiny, poses intriguing challenges to Foucauldian-inspired theorizations of agency, and opens novel possibilities for thinking of agency and (inter)subjectivity beyond intentionality, desire, and rational understanding. As this collection shows, local cosmologies of destiny do often accord people the capacity, and responsibility, to act in their lives. However, when located at the intersection of worldly and tran- scendental powers, ideas of destiny deeply complicate the relationship between action and intentionality. This emerges clearly in Guinness's article, where agency emerges as the capacity of working toward a convergence of human and divine intentionality, revealing an embodied dynamic of divine and human will.

As the authors of this collection show so well, the space for action opened at the intersection of human and divine or cosmological power is never absoluteit is a freedom containing and contained by multiple unfreedoms. Reflecting recent anthropological (re)theorizations of agency (Mahmood 2005), destiny compels us to conceptualize freedom as the capacity to act within the limits set by divine/cosmic power, rather than as the capacity to overcome them (cf. Foucault 1976; see also Jackson 2011; Laidlaw 2013; Menin 2015; Schielke 2015: 225). An anthropology of destiny is, in this sense, also (and inevitably so) an anthropological reflection on power(s) - a crucial question discussed further in Samuli Schielke's afterword. Such powers generally emerge in and through time: destiny's "composite temporality" (Hatfield 2002) constitutes a critical dimension of the malleable fixity discussed thus far.

\section{Unfixed time}

The ethnographies in this collection reveal how destiny has an intimate, deeply enigmatic relationship with time. Time is a key trope through which theories of destiny are formulated, and different temporal positionings of the ethnographic and theoretical gaze can themselves generate radically different understandings of destiny and its efficacy. This is not only because reckoning with destiny requires specific temporal knowledge and careful temporal practices (Hatfield 2002; Nevola, this issue), but also because destiny's malleable fixity is often positioned in time, and reveals itself through timefrom a person's lifetime (e.g., Homola, this issue; Last 2013), to the unfolding of human history itself (see Palmié and Stewart 2015).

Ethnographic conceptions of destiny often fold, within it, multiple temporal dimensions, interrogating linear theorizations, and expectations, of time. The pre- in the English word predestination already points to this multilayered temporality, indicating that something has been determined, willed, or known prior to its emergence in human life. In diverse religious traditions, one's personal destiny is understood to be determined prior to birth itself, prenatal destiny being a common theme across a variety of anthropological studies (e.g., Course 2014; Fortes 
1959; Guenzi 2013). In Islam, one's destiny is determined when soul and body are united (De Cillis 2014), while in Yoruba thought, personal destiny (ori) is shaped in heaven and actualized throughout a life course (Balogun 2007). Similarly, in Hinduism and Buddhism, the idea of karma hinges on the ways in which previous states of existence determine a person's present and future (Keyes and Daniel 1983).

In these different cases, a determining decision taken at the beginning, or conception, of a person's life, gradually reveals itself as present time progresses. This is why many divinatory practices connected with destiny are predictive, prospective, anticipatory - trying to anticipate something that is to come in the future, but has been determined, willed, or known prior to its emergence. For Guinness, the rugby player's body becomes a temporal agent containing the potential to actualize a desirable sporting future still to come as well as the physical/spiritual terrain where one is expected to cultivate such a "fixed" future.

However, destiny is not only about imagining, and practicing, the future. Both Nevola and Homola show how destiny constitutes a complex temporal horizon in relation to which one may also, retrospectively, observe and understand the past. As a potent ordering narrative of the past, destiny becomes a meaningful frame (Crapanzano 2014), a native narrative (Course 2014; Hatfield 2002; Homola, this issue) or theory (Schielke 2015), or a symbolic or reflexive discourse (Nevola, this issue; Nieswand 2010). And by providing a retrospective "necessary quality" to events experienced in the moment as random, futile, and even cruel (misfortune, failure, illness), destiny offers a transcendental order that is not only temporal but also meaningful (Crapanzano 2014; cf. Evans-Pritchard 1976). Unlike randomness or chance, then, destiny's specific purpose, albeit often unknown or even unknowable to humans, allows one to look back at an event and explain it precisely in terms of its (malleable) fixity, and even necessity. If, as David Graeber notes, a constitutive aspect of the human experience of history itself is the fact that "the unpredictable is constantly turning into the irreversible" (2012: 25), destiny enables people to select specific incidents (or critical durations; Nevola, this issue) in the flow of human life, and transform them into a concatenation of necessary and even meaningful events.

This focus on the ex post facto and "functional" qualities of destiny has been critiqued by some anthropologists (Elliot 2016; Hamdy 2009; Mittermaier 2012) for the risk it runs of portraying destiny simply as a "le- gitimizing or comforting device" (Mittermaier 2012: 258). Indeed, the articles in the collection show how destiny is never just a discursive device for rationalizing past failures or indexing human/divine relationshipsit is also a tangible operating force to be reckoned with, ethnographically and conceptually, in the present. By attending to the specific temporal moment of destiny's emergence in Taiwanese social life, Homola, for example, argues that destiny, far from preceding enunciation, comes into being in and through language. This language of destiny powerfully "catches" those involved in its fated logics by requiring human participation, responsibility, and imagination.

Destiny's complex relationship with time testifies to destiny's constitutive tensions between fixity and malleability, certainty and uncertainty, and, ultimately, human and divine powers. Indeed, perhaps the most striking effect of constructing destiny as a comparative category, as we begin to do in this collection, is the discovery of the logical and ethnographic tensions, contradictions, even paradoxes, contained within the category itself (cf. Berliner 2016). It is precisely this tension, contradiction, paradox, we argue, that makes destiny such a potent trigger for anthropological "mental gymnastics" (Lévi-Strauss 1994: 11), and it is to the gymnastics that destiny requires of anthropology that the collection is dedicated.

\section{Acknowledgments}

We are thankful to HAU editors Giovanni da Col and Michael Lambek and the anonymous reviewers for their generous engagement with this collection. Our warm thanks also to Lorenzo D'Angelo, Hilary Foye, Soumhya Venkatesan and the "Cosmologies of Destiny" workshop participants, and everyone who has supported us throughout the project.

\section{References}

Balogun, Oladele Abiodun. 2007. "The concepts of ori and human destiny in traditional Yoruba thought: A soft deterministic interpretation." Nordic Journal of African Studies 16, no. 1: 116-30.

Bargdill, Richard, W. 2006. "Fate and destiny: Some historical distinctions between the concepts." Journal of Theoretical and Philosophical Psychology 26: 205-20.

Berliner, David, ed. 2016. "Anthropology and the study of contradictions." HaU: Journal of Anthropological Theory 6, no. 1: 1-27. 
Course, Magnus. 2014. "The end of me: Mapuche narratives of destiny." In Fluent selves: Autobiography, person, and history in lowland South America, edited by Suzanne Oakdale and Magnus Course, 144-64. Lincoln: University of Nebraska Press.

Crapanzano, Vincent. 2014. "Half disciplined chaos: Thoughts on destiny, contingency, story, and trauma." In Genocide and mass violence: Memory, symptom, and recovery, edited by Devon E. Hinton and Alexander L. Hinton, 157-72. Cambridge: Cambridge University Press.

da Col, Giovanni. 2012. "Introduction: Natural philosophies of fortune-luck, vitality, and uncontrolled relatedness." Social Analysis 56, no. 1: 1-23.

da Col, Giovanni, and Caroline Humphrey, eds. 2012a. "Cosmologies of fortune: Luck, vitality and uncontrolled relatedness." Special issue, Social Analysis 56, no. 1.

, eds. 2012b. "Future and fortune: Contingency, morality and the anticipation of everyday life." Special issue, Social Analysis 56, no. 2.

D’Angelo, Lorenzo. 2015. “'Diamond mining is a chain': Luck, blessing, and gambling in Sierra Leone's artisanal mines." Critical African Studies 7, no. 3: 243-61.

De Cillis, Maria. 2014. Free will and predestination in Islamic thought: Theoretical compromises in the works of Avicenna, Al-Ghazali and Ibn 'Arabi. Abingdon: Routledge.

Douglas, Mary. (1966) 2001. Purity and danger: An analysis of concepts of pollution and taboo. London: Routledge.

Elliot, Alice. 2016. "The makeup of destiny: Predestination and the labor of hope in a Moroccan emigrant town." American Ethnologist 43, no. 3: 488-99.

Evans-Pritchard, E. E. 1976. Witchcraft, oracles, and magic among the Azande. Oxford: Clarendon.

Festa, Paul. 2007. "Mahjong agonistics and the political public in Taiwan: Fate, mimesis, and the martial imaginary." Anthropological Quarterly 80, no. 1 (Winter): 93-125.

Fortes, Meyer. 1959. Oedipus and Job in West African religion. Cambridge: Cambridge University Press.

Foucault, Michael. 1976. Histoire de la sexualité.Vol I: La Volonté de savoir. Paris: Gallimard.

Gaibazzi, Paolo, and Marco Gardini, eds. 2015. "Fate and fortune in Africa." Special issue, Critical African Studies 7 , no. 3 .

Giddens, Anthony. 2010. "Introduction." In The Protestant ethic and the spirit of capitalism, vii-xxiv. New York: Scribner's Sons.
Graeber, David. 2012. "The sword, the sponge, and the paradox of performativity: Some observations on fate, luck, financial chicanery, and the limits of human knowledge." Social Analysis 56, no. 1: 25-42.

Guenzi, Caterina. 2013. Le discours du destin: La pratique de l'astrologie à Bénarès. Paris: CNRS Editions.

Hamdy, Sherine. 2009. "Islam, fatalism, and medical intervention: Lessons from Egypt on the cultivation of forbearance (Sabr) and reliance on God (Tawakkul)." Anthropological Quarterly 82, no. 1: 173-96.

Harrell, Stevan. 1987. "The concept of fate in Chinese folk ideology.” Modern China 3, no. 1: 90-109.

Hatfield, Donald J. 2002. "Fate in the narrativity and experience of selfhood: A case from Taiwanese Chhiam Divination." American Ethnologist 29, no. 4: 857-77.

Herzfeld, Michael. 1992. The social production of indifference: Exploring the symbolic roots of western bureaucracy. Chicago: University of Chicago Press.

Holbraad, Martin. 2012. Truth in motion: The recursive anthropology of Cuban divination. Chicago: University of Chicago Press.

Ingersoll, Jasper, ed. 1966. "Fatalism in Asia: Old myths and new realities." Special issue, Anthropological Quarterly 39, no. 3.

Jackson, Michael. 1988. "In the thrown world: Destiny and decision in the thought of traditional Africa." In Choice and morality in anthropological perspective, edited by George N. Appell and Triloki N. Madan, 193-210. Albany: State University of New York Press.

- 2011. Life within limits: Well-being in a world of want. Durham, NC: Duke University Press.

Jamous, Raymond. 1981. Honneur et Baraka: Les structures sociales traditionnelles dans le Rif. Paris: Ed. de la Maison des Sciences de l'Homme.

Kent, Eliza. 2009. "What's written on the forehead will never fail: Karma, fate, and headwriting in Indian folktales." Asian Ethnology 68, no. 1: 1-26.

Keyes, Charles F., and E. Valentine Daniel. 1983. Karma: An anthropological enquiry. Berkeley: University of California Press.

Laidlaw, James. 2013. The subject of virtue: An anthropology of ethics and freedom. Cambridge: Cambridge University Press.

Lambek, Michael. 1993. Knowledge and practice in Mayotte: local discourses of Islam, sorcery, and spirit possession. Toronto: University of Toronto Press. 
Last, Murray. 2013. "Dying on time: Cultures of death and time in Muslim Northern Nigeria." In Taming time, timing death: Social technologies and rituals, edited by Dorthe Refslund Christensen and Rane Willerslev, 247-64. Farnham: Ashgate.

Lawal, Babatunde. 1985. "Ori: The significance of the head in Yoruba sculpture." Journal of Anthropological Research 41, no. 1: 91-103.

Lévi-Strauss, Claude. 1994. The raw and the cooked. London: Pimlico.

Lupke, Christopher, ed. 2005. The magnitude of ming: Command, allotment, and fate in Chinese culture. Honolulu: University of Hawai'i Press.

Mahmood, Saba. 2005. Politics of piety: The Islamic revival and the feminist subject. Princeton, NJ: Princeton University Press.

Menin, Laura. 2015. “The impasse of modernity: Personal agency, divine destiny, and the unpredictability of intimate relationship in Morocco." Journal of the Royal Anthropological Institute 21, no. 4: 892-910.

. 2016. "'Men are not scared! (rijjala ma tay-khafosh)': Luck, destiny and the gendered vocabularies of clandestine migration in central Morocco." Archivio Antropologico Mediterraneo 18, no. 1: 25-36.

Mittermaier, Amira. 2012. "Dreams from elsewhere: Muslim subjectivities beyond the trope of self-cultivation." Jour- nal of the Royal Anthropological Institute 18, no. 2: 24765.

Nieswand, Boris. 2010. "Enacted destiny: West African charismatic Christians in Berlin and the immanence of God." Journal of Religion in Africa 40, no. 1: 33-59.

Obeyesekere, Gananath. 2002. Imagining karma: Ethical transformation in Amerindian, Buddhist, and Greek rebirth. Berkeley: University of California Press.

Palmié, Stephan, and Charles Stewart. 2015. "Introduction: For an anthropology of history." HaU: Journal of Anthropological Theory 6, no. 1: 207-36.

Sangren, P. Steven. 2012. "Fate, agency, and the economy of desire in Chinese ritual and society." Social Analysis 56, no. 2: $117-35$.

Schielke, Samuli. 2015. Egypt in the future tense: Hope, frustration and ambivalence before and after 2011. Bloomington: Indiana University Press.

Rapp, Rayna, Deborah Heath, and Karen-Sue Taussig. 2001 "Genealogical dis-ease: Where hereditary abnormality, biomedical explanation, and family responsibility meet." In Relative values: Reconfiguring kinship studies, edited by Sarah Franklin and Susan McKinnon, 384-409. Durham, NC: Duke University Press.

Weber, Max. 2010. The Protestant ethic and the spirit of capitalism. Translated by Talcott Parsons. New York: Scribner's Sons.

Alice ElLIOT is Lecturer in Anthropology at Goldsmiths, University London. Her research focuses on Morocco, Tunisia, and Europe, and she writes on Mediterranean migrations, Islam, hope, and revolution, kinship, intimacy, and the imagination of gender. She is co-editor of Methodologies of mobility: Ethnography and experiment (Berghahn, 2017).

Alice Elliot

Department of Anthropology Goldsmiths, University of London

8 Lewisham Way

London SE14 6NW

a.elliot@gold.ac.uk 
Laura Menin is a Postdoctoral Fellow at the University of Milano Bicocca. She has worked on love and intimacy, Islam, migration, political violence, and racism and "post-slavery." She is the editor (with Elisabetta Costa) of the special issue for Middle East Journal of Culture and Communication, "Digital intimacies: Exploring digital media and intimate lives in the Middle East and North Africa" (2016). She is currently preparing a book tentatively titled Quest for love: Freedom, destiny and moral anxieties in central Morocco.

Laura Menin

Department of Sociology and Social Research

University of Milano-Bicocca

Via Bicocca degli Arcimboldi 8

20126 Milano

Italy

laura.menin@unimib.it 